\title{
Front Matter: Volume 11758
}

, "Front Matter: Volume 11758," Proc. SPIE 11758, Unmanned Systems Technology XXIII, 1175801 (11 May 2021); doi: 10.1117/12.2598687

SPIE. Event: SPIE Defense + Commercial Sensing, 2021, Online Only 


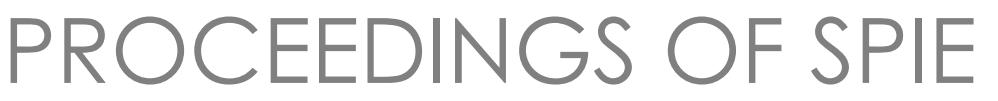

\title{
Unmanned Systems Technology XXIII
}

\author{
Hoa G. Nguyen \\ Paul L. Muench \\ Brian K. Skibba \\ Editors
}

12-16 April 2021

Online Only, United States

Sponsored and Published by

SPIE 
The papers in this volume were part of the technical conference cited on the cover and title page. Papers were selected and subject to review by the editors and conference program committee. Some conference presentations may not be available for publication. Additional papers and presentation recordings may be available online in the SPIE Digital Library at SPIEDigitalLibrary.org.

The papers reflect the work and thoughts of the authors and are published herein as submitted. The publisher is not responsible for the validity of the information or for any outcomes resulting from reliance thereon.

Please use the following format to cite material from these proceedings:

Author(s), "Title of Paper," in Unmanned Systems Technology XXIII, edited by Hoa G. Nguyen, Paul L. Muench, Brian K. Skibba, Proc. of SPIE 11758, Seven-digit Article CID Number (DD/MM/YYYY); (DOI URL).

ISSN: 0277-786X

ISSN: 1996-756X (electronic)

ISBN: 9781510643536

ISBN: 9781510643543 (electronic)

Published by

SPIE

P.O. Box 10, Bellingham, Washington 98227-0010 USA

Telephone +1 3606763290 (Pacific Time)

SPIE.org

Copyright @ 2021 Society of Photo-Optical Instrumentation Engineers (SPIE).

Copying of material in this book for internal or personal use, or for the internal or personal use of specific clients, beyond the fair use provisions granted by the U.S. Copyright Law is authorized by SPIE subject to payment of fees. To obtain permission to use and share articles in this volume, visit Copyright Clearance Center at copyright.com. Other copying for republication, resale, advertising or promotion, or any form of systematic or multiple reproduction of any material in this book is prohibited except with permission in writing from the publisher.

Printed in the United States of America by Curran Associates, Inc., under license from SPIE.

Publication of record for individual papers is online in the SPIE Digital Library.

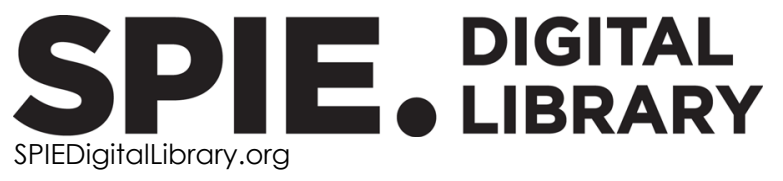

Paper Numbering: A unique citation identifier (CID) number is assigned to each article in the Proceedings of SPIE at the time of publication. Utilization of CIDs allows articles to be fully citable as soon as they are published online, and connects the same identifier to all online and print versions of the publication. SPIE uses a seven-digit CID article numbering system structured as follows:

- The first five digits correspond to the SPIE volume number.

- The last two digits indicate publication order within the volume using a Base 36 numbering system employing both numerals and letters. These two-number sets start with 00, 01, 02, 03, 04, 05, 06, 07, 08, 09, 0A, OB ... 0Z, followed by 10-1Z, 20-2Z, etc. The CID Number appears on each page of the manuscript. 


\section{Contents}

NOVEL ROBOT DESIGNS

1175802 Optimization of energy consumption for hexapod robot following inclined path using nontraditional gait [11758-1]

1175805 Orientation stabilization in a bioinspired bat-robot using integrated mechanical intelligence and control [11758-4]

1175806 Mechanical design and fabrication of a kinetic sculpture with application to bioinspired drone design [11758-5]

$1175807 \quad$ HSMET: a lightweight transport robot [1 1758-6]

1175808 Dynamic modeling and real-time evaluation of reaction forces and torques of hexapod robot [11758-30]

AUTONOMOUS GROUND VEHICLES: JOINT SESSION WITH VOLUMES 11748 AND 11758

1175809 Sequence risk and bond tents [11758-7]

$11758 \mathrm{OA}$ Using vision navigation and convolutional neural networks to provide absolute position aiding for ground vehicles [11758-8]

$11758 \mathrm{OB} \quad$ Frequency modulated imaging radar using distributed frequency swept antennas [11758-9]

ARTIFICIAL INTELLIGENCE/MACHINE LEARNING AND UNMANNED SYSTEMS: JOINT SESSION WITH VOLUMES 11746 AND 11758

11758 OC Multi-agent autonomous battle management using deep neuroevolution [1 1758-10]

11758 OD Convolutional neural networks and particle filter for UAV localization [1 1758-1 1]

11758 OE Deep convolutional object detection and search area prediction for UAV tracking [1 1758-12] 
UAV TECHNOLOGIES, TESTBEDS, AND APPLICATIONS

11758 OG Simulation environment for development of quad-copter controls incorporating physical environment in urban setting [11758-14]

$11758 \mathrm{OH}$ VADER: a hardware and simulation platform for visually aware drone autonomy research [11758-15]

SELF ORGANIZING, COLLABORATIVE UNMANNED ISR ROBOTIC TEAMS: JOINT SESSION WITH VOLUMES 11753 AND 11758

$11758 \mathrm{OM}$ Value at risk strategies for robot swarms in hazardous environments [11758-20]

DYNAMIC PLANNING AND PREDICTION

$11758 \mathrm{ON} \quad$ Improving success and efficiency of underwater autonomous tasks through dynamic re-planning and episodic reasoning [11758-21]

$1175800 \quad$ Fast terrain traversability estimation with terrestrial lidar in off-road autonomous navigation [11758-22]

$11758 \mathrm{OP} \quad$ Game theory framework for agent decision-making in communication constrained environments [11758-23]

11758 OR Indoor path-planning for a tracked mobile robot using Dijkstra's algorithm and ROS [11758-31]

\section{POSTER SESSION}

11758 OS Making the Milrem Themis UGV ready for autonomous operations [1 1758-25]

11758 OT Application of the sliding innovation filter to unmanned aerial systems [11758-26]

11758 OV Development of a methodology for determining overgrown agricultural fields based on data from unmanned aerial vehicles on computer vision [11758-28] 